REVIEW ARTICLE

\title{
FROM DARK TO LIGHT AND BACK AGAIN: IS PINNA NOBILIS, THE LARGEST MEDITERRANEAN BIVALVE, ON THE BRINK OF EXTINCTION?
}

\author{
Fabio Scarpa $^{1 \dagger}$, Daria Sanna ${ }^{2 \dagger}$, Ilenia Azzena ${ }^{1,2}$, Piero Cossu ${ }^{1}$, Marco Casu $^{1 *}$
}

${ }^{1}$ Department of Veterinary Medicine, University of Sassari

Sassari, Italy

${ }^{2}$ Department of Biomedical Sciences, University of Sassari

Sassari, Italy

$\uparrow$ Fabio Scarpa and Daria Sanna equally contributed to this paper

\section{"Corresponding author:}

Prof. Dr. Marco Casu

Department of Veterinary Medicine,

University of Sassari

Sassari, Italy

Via Vienna 2, 07100 Sassari, Italy

+39079 228924; +393284354905

ORCID: 0000-0002-5042-4851

E-mail: marcasu@uniss.it

\section{Original Submission:}

10 February 2021

Revised Submission:

24 February 2021

Accepted:

01 March 2021

\begin{abstract}
Pinna nobilis is the largest bivalve of the Mediterranean Sea, where it represents a flagship species. As a possible consequence of several human disturbing activities, at the beginning of the ' $80 \mathrm{~s}$, populations of fan mussel started a severe demographic decline. To reverse this trend, $P$. nobilis was included in a regime of full protection which led to a significant recovery of the species at the start of the millennium. Unfortunately, P. nobilis is presently facing a dramatic epidemic, which is bringing this species to the brink of extinction. This phenomenon started in early autumn 2016, from the Mediterranean coasts of Spain. Since then, the mass mortality of fan mussels spread quickly eastward reaching almost all Mediterranean areas. First epidemiological surveys ascribed this phenomenon to the infection of the protozoan Haplosporidium pinnae, but recent studies indicated some species of bacteria belonging to the genera Mycobacterium and Vibrio as further or alternative etiological agents. Presently, a multifactorial disease, mediated by the combined action of several pathogens, seems to be the most probable responsible factor which is favouring the mass mortality of $P$. nobilis. Despite its conservational prominence, a low number of studies investigated the genetic structure of $P$. nobilis before its mass mortality and all were consistent in evidencing a very good health for populations throughout the whole Mediterranean, pointing out high levels of genetic variability and good genetic connectivity among areas. Now it would be useful to provide an extended post-epidemic molecular survey.
\end{abstract}

Keywords: Fan mussel, threatened species, mass mortality, genetic variability, pathogens 


\section{INTRODUCTION}

\section{A white flag in the Mediterranean Sea? \\ Biological traits of the threatened to extinction \\ Pinna nobilis}

The species Pinna nobilis (Linnaeus 1758), also known as fan mussel or noble pen shell (Fig. 1) is a bivalve belonging to the order Ostreoida Fërussac 1822, and the family Pinnidae Leach 1819.

Pinna nobilis represents the largest bivalve populating the Mediterranean Sea (Rabaoui et al., 2008), and one of the largest in the world since it can exceed one meter of total length (Zavodnik et al., 1991). This bivalve shows a shell with sturdy triangular shaped valves. The apex of the shell is sunken in the soft bottom and anchored, standing upright, to the substrate by means of the byssus which is a bundle of protein hold fast fibers secreted by an organ named byssus gland (Diana et al., 2017). By means of the byssus, individuals are able to keep attached to a solid surface and withstand currents and coastal hydrodynamics.
Pinna nobilis lives in coastal waters at 0.5 to 60 meters depths (Butler et al., 1993), typically in mixed seagrass meadows of Posidonia oceanica, Cymodocea nodosa (Zavodnik et al., 1991), Zostera marina or Zostera noltii (Voultsiadou et al., 2010), and occasionally on the bare sandy substrates and maërl beds (Basso et al., 2015).

This species is considered one of the most longlived bivalves (Rouanet et al., 2015; García-March et al., 2020a); so far, longevity of $P$. nobilis has been estimated to 20 years by Butler et al. (1993), to 9-12 years by Richardson et al. (2004), and over than 20 years by Galinou-Mitsoudi et al. (2006) and García-March et al. (2011). More recently Rouanet et al. (2015) reported two individuals about 45 years old on a population in Port-Cros Island (Provence, France). However, the knowledge on life expectancy of fan mussels is still incomplete (see e.g. Rouanet et al., 2015), since designing an experimental plan which allow to assess the maximum species lifespan under non-disturbed conditions is very difficult.

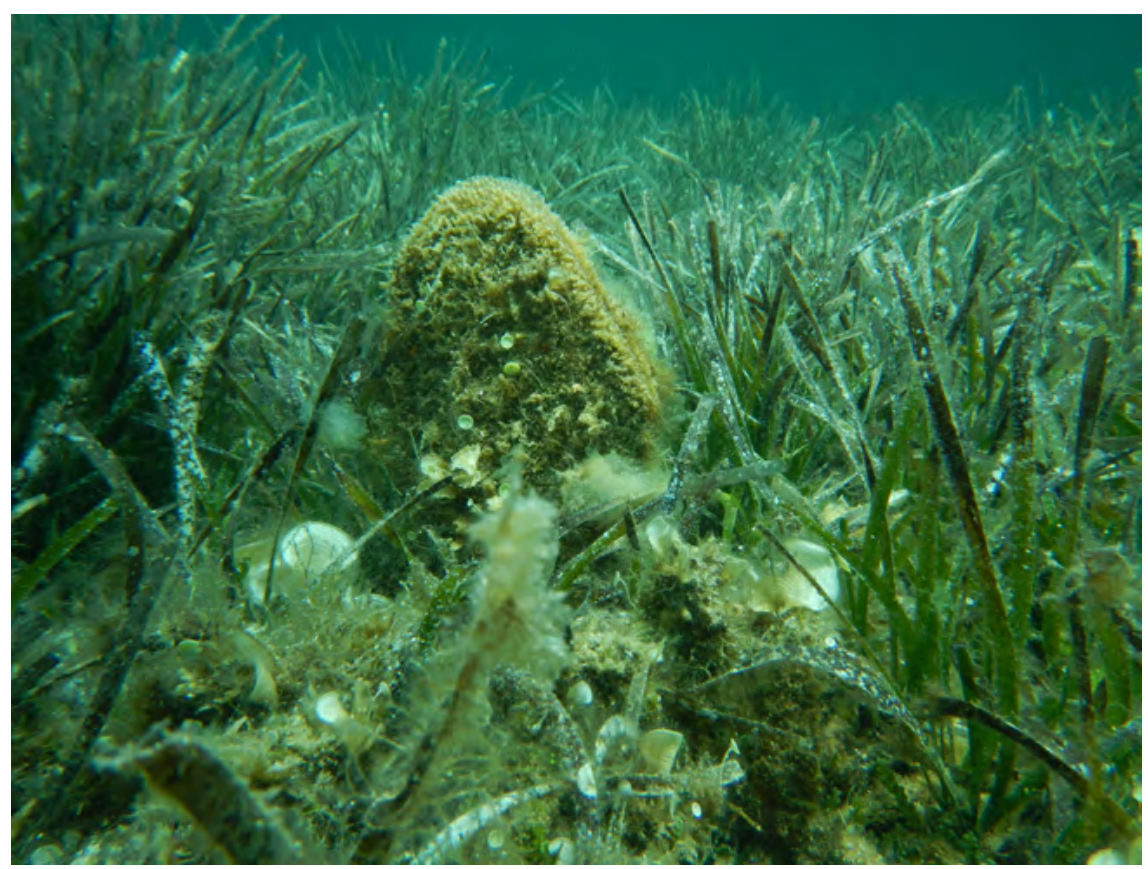

Figure 1 Individual of Pinna nobilis found alive in 2019 , showing no signs of disease after external stimulation.

Photo by Fabio Scarpa 
In the Mediterranean basin, P. nobilis is one of the best-known marine invertebrates and represents an important endemic species. For this reason, the species as been regarded in the Mediterranean area as a flagship species, sensu Walpole and Leader-Williams (2002) and Heywood (1995), which during years was able to provide support for biodiversity conservation in specific places or social contexts. The ecological importance of $P$. nobilis relies on its role as key species in the marine environment, since this species is a habitat former, which enhance the biotic and abiotic complexity of benthic communities (Rabaoui et al., 2015). P. nobilis may be regarded as a biodiversity promoter as its valves represent an extended, almost always vertical, hard surface in soft bottoms (see e.g. Fig. 2), which can be colonized by hard-bottom benthic species, such as algae, sponges, mollusks (including other bivalves), and polychaetes (Corriero and Pronzato, 1987; Giacobbe, 2002; Addis et al., 2009, Rabaoui et al., 2009). Remarkably, this species hosts the crustaceans Pontonia pinnophylax and Nepinnotheres pinnotheres (Rabaoui et al., 2008). Pinna nobilis also plays a pivotal role in the trophic web, being a prey of other species, such as Octopus vulgaris (García-March et al., 2006). As all of the representatives of its family, $P$. nobilis is a filterfeeder species, whose populations may filter water in the amount of 6 liter/min (Zavodnik et al., 1991; Schultz and Huber, 2013). In this context, it is noteworthy the role of this species as bioindicator of the quality of coastal waters (IOPR, 2003).

Pinna nobilis is a simultaneous hermaphrodite species, with an asynchronous maturation which prevent self-fertilization, with gonads in acinaceous glands (De Gaulejac, 1995). Sexual maturity is reached after the first two years and the sexual cycle is divided into four stages: 1) sexual repose, characterized by few acines reduced in volume, 2) sexual activity, characterized by the beginning of the developmental stage for both sexes, 3) emission of germinal products, characterized by an alternate spawning and gametogenesis, and 4) last partial maturation before the return to sexual repose. The cycles follow each other and the individual sexual maturity is continuous during summer with a sexual gender alternation in order to further avoid self-fertilization (Gosling, 2003).

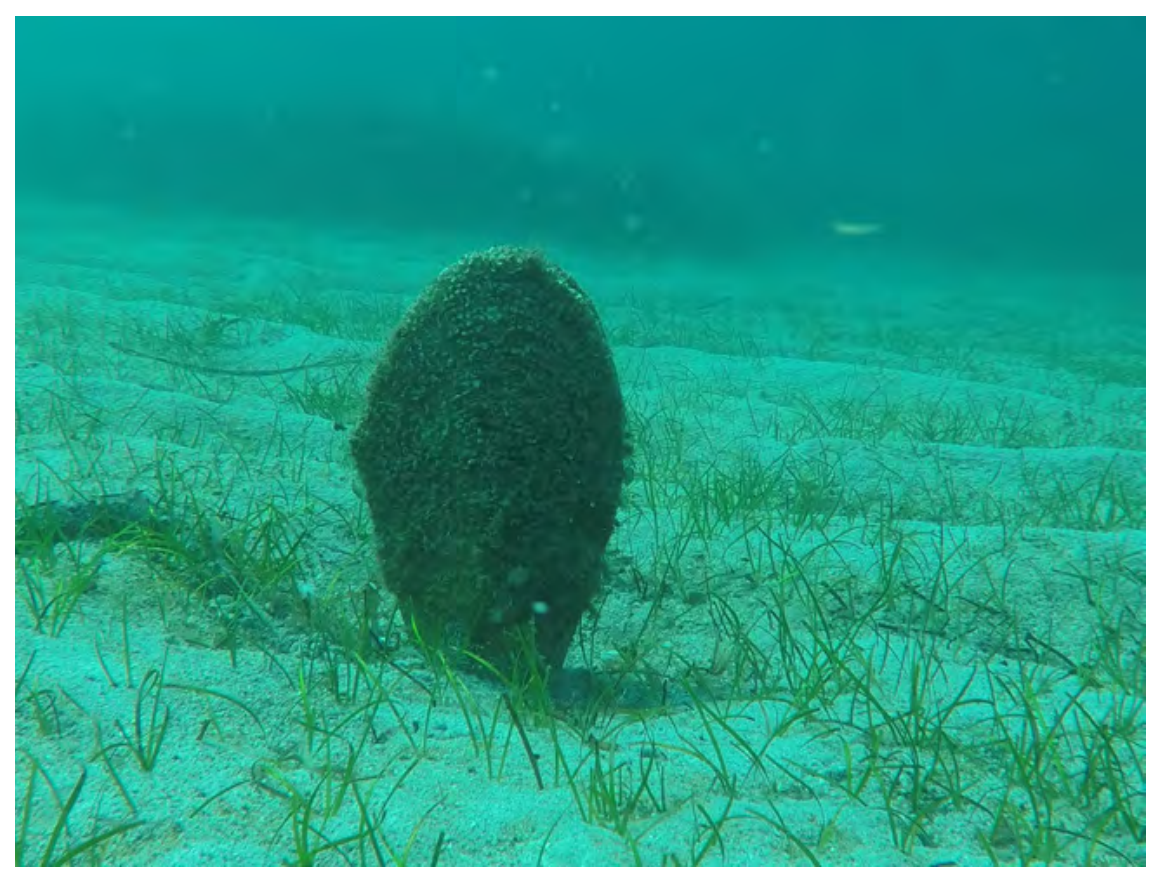

Figure 2 Individual of Pinna nobilis, which, in this case, represents the only hard substrate for several meters in a sandy bottom.

Photo by Fabio Scarpa 
As most sessile or with very limited movement capabilities organisms, $P$. nobilis relies on a pelagic early life stage to spread out. Its veliger-stage larvae drifts in the water column and exhibits, as other bivalves (Gosling, 2003), daily vertical migration, spending night-time in superficial sea layers (Peharda and Vilibić, 2008).

Specific details on the length of the larval lifecycle, as well as other factors influencing survival rates and behavior, are poorly known (Trigos et al., 2018). De Gaulejac and Vicente (1990) postulated a larval duration in open waters of about $5-10$ days, before veliger settling in the sediment and anchoring by means of the byssus.

\section{Light after darkness: Pinna nobilis recovered after centuries of abuse of man}

Pinna nobilis was historically spread and very common in the whole Mediterranean basin, being improperly overexploited during past centuries, mainly for human consumption, jewelry fabrication and wearing. The first reported case of exploitation of $P$. nobilis dates back to ancient times, since Egyptians and Romans were used to employ byssus filaments for the manufacture of the so-called "sea silk", to create high-valued textiles and clothing luxury (Maeder, 2008). The intense harvesting, aimed to collect the byssus for obtaining a golden shimmering textile fibre, continued up to recent time (Rabaoui et al., 2010), especially in the South of the island of Sardinia (authors pers. comm).

Moreover, $P$. nobilis has been also intensely harvested to collect its shells, which were used for the manufacturing of ornamental jewels, precious buttons, knife handles, etc. (Butler et al., 1993; Rabaoui et al., 2010). More recently, in the mid of the last century, the habit to use the abductor muscle of $P$. nobilis as a culinary ingredient and the remaining whole body as a bait for fishing purposes, became common (Greenwald, 1996).

In addition to these direct causes, populations of P. nobilis were also critically affected by indirect human actions, such as boat anchoring, pollution, habitat fragmentation, and bycatch (Vázquez-Luis et al., 2015; Öndes et al., 2020a). In this context, it should be pointed out that the semi-enclosed nature of the Mediterranean Sea - with many densely populated coastal zones - magnifies the negative effects linked to the human interaction with marine environment (Coll et al., 2010; Hendriks et al., 2013; Vázquez-Luis et al., 2015).

As a consequence of all disturbing activities, at the beginning of the ' $80 \mathrm{~s}$, populations of $P$. nobilis started a demographic decline which became very severe at the end of the decade (Öndes et al., 2020b). In order to invert this trend, P. nobilis was included in a full protection regime under the Annex II of the Barcelona Convention (SPA/ BD Protocol 1995) and Annex IV of the EU Habitats Directive (European Council Directive 92/43/EEC). Furthermore, in Italy, the Legislative Decree 190/2010, Art. 11 for the Marine Strategy Monitoring Program included in 2010 the fan mussel among the Mediterranean species worthy of particular attention. Anyhow, it should be noted that in several South-western areas of the Mediterranean Sea, European and national conservation policies have been poorly followed and individuals were often illegally exploited for consumption (Katsanevakis et al., 2011) or for decorative purposes (Kersting et al., 2019).

In few decades, the regime of full protection led to a significant recovery of the species, which showed a demographic renewal in the whole Mediterranean basin (see e.g. Sanna et al., 2013, 2014). For instance, in 2012 some of the authors of the present review participated to an extensive sampling campaign, focused to collect small tissue samples for a molecular survey (see Fig. 1 in 
Sanna et al., 2013), in which they observed very numerically abundant population with many sites hosting more than 100 individuals.

\section{Dancing on the edge of the abyss: mass mortality runs over Pinna nobilis}

Against of this extraordinary recovery mediated by both protection regimes and specific biological features of the species, Pinna nobilis is presently facing a dramatic epidemic which is threatening its survival till to the extinction. Indeed, what lies before us is a dramatic situation without precedent reports in large mollusks, with never recorded before mortality rates and speed of propagation (Cabanellas-Reboredo et al., 2019; García-March et al., 2020b). The only exception to such an almost unique phenomenon was represented by the Pinnidae Atrina pectinata, for which a similar mass mortality was reported, but not extended to the whole range of distribution of the species (Maeno et al., 2006).

This as sad as unexpected event for $P$. nobilis began in early autumn 2016, when an abnormally high mortality of fan mussels was detected in the Mediterranean coasts of Spain (CabanellasReboredo et al., 2019 and references therein). Lande (1993) defined a demographic catastrophic phenomenon that is able to affect simultaneously all life stages of a species as Mass Mortality Event (MME). On that basis, Vázquez-Luis et al. (2017) defined the death of a great number of individuals of P. nobilis as MME in their paper entitled 'S.O.S. Pinna nobilis: A Mass Mortality Event in Western Mediterranean Sea', which thus represents the first scientific report for this phenomenon.

Since then, the situation worsened quickly, with the mass mortality affecting different Mediterranean areas expanding in an eastward direction, and gradually involving Spanish, French, Italian, Croatian, Bosnians and Herzegovinians, Greek and
Turkish coasts (Catanese et al., 2018, Katsanevakis et al., 2019, Panarese et al., 2019; CabanellasReboredo et al., 2019; Lattos et al., 2020; GarcíaMarch et al., 2020a; Šarić et al., 2020; Čelebičić et al., 2020).

This phenomenon had a great impact on the populations of $P$. nobilis in a very short timeframe. An example of how many quick this phenomenon spread is represented by the case of the Asinara Island (an Italian national park placed in North $\square$ West of Sardinia), whose populations dramatically disappeared in few months (see Scarpa et al., 2019). Indeed, at the beginning of 2018, during the census of $P$. nobilis performed for the "Marine Strategy Monitoring Program", first signs of decay of the population were detected. In July of the same year, the mortality reached about $50 \%$, while in November almost $90 \%$ of $P$. nobilis was found dead. At the beginning of the mass mortality, it was a common occurrence the finding of individuals still standing upright, with tissues collapsed in the bottom of the shell (Fig. 3), with empty shell (Fig. 4), or with shell colonized by other species (e.g. O. vulgaris, which uses the valves as lair, see Fig. 5). Instead, during the advanced stage of the epidemic, it was common to find individuals with the shell detached completely from the bottom, in diverse degradation status (Fig. 6).

The signs of an unknown pathology progression are evident in almost all areas affected by MME. At the beginning of what is considered as a disease, sick individuals show an anomalous slow closure of valves after external stimulation. In a short time (advanced phase of the disease), individuals suffer a detaching of the mantle from valves being no longer able to completely close them (Vázquez-Luis et al., 2017), thus becoming highly vulnerable to predation. In the final phase of the disease, the mantle moves down in the bottom of the shell and individuals generally do not survive more than a few days. 

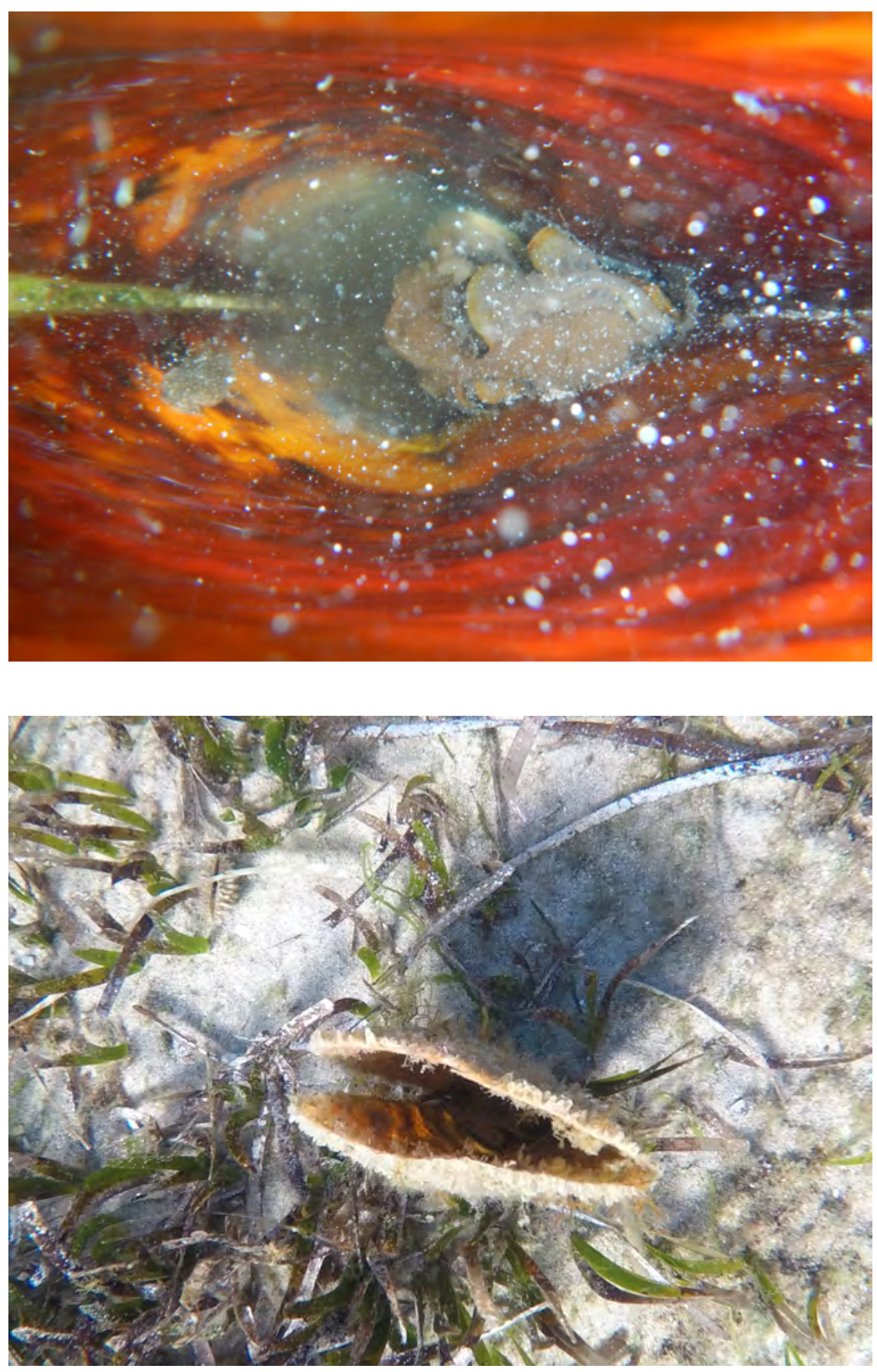

Figure 3 Internal of a dead, still standing upright individual of Pinna nobilis, with tissues collapsed in the bottom of the shell. Photo by Fabio Scarpa
Figure 4 Empty shell of a died individuals of Pinna nobilis.

Photo by Fabio Scarpa
Immediately after first reports of MME for the Spanish coasts, several scientific studies started with the aim to understand which pathogens might be involved in the disease-linked mortality of $P$. nobilis. Vázquez-Luis et al. (2017) reported the presence of a haplosporidan-like parasite that affects the digestive system of fan mussels, progressively reducing the feeding capability of individuals and causing their death. Subsequently, epidemiological surveys ascribed the mass mortality to the protozoan Haplosporidium pinnae, described as a new species by Catanese et al. (2018) and initially reported as host-specific for $P$. nobilis. This finding was consistent to what found 

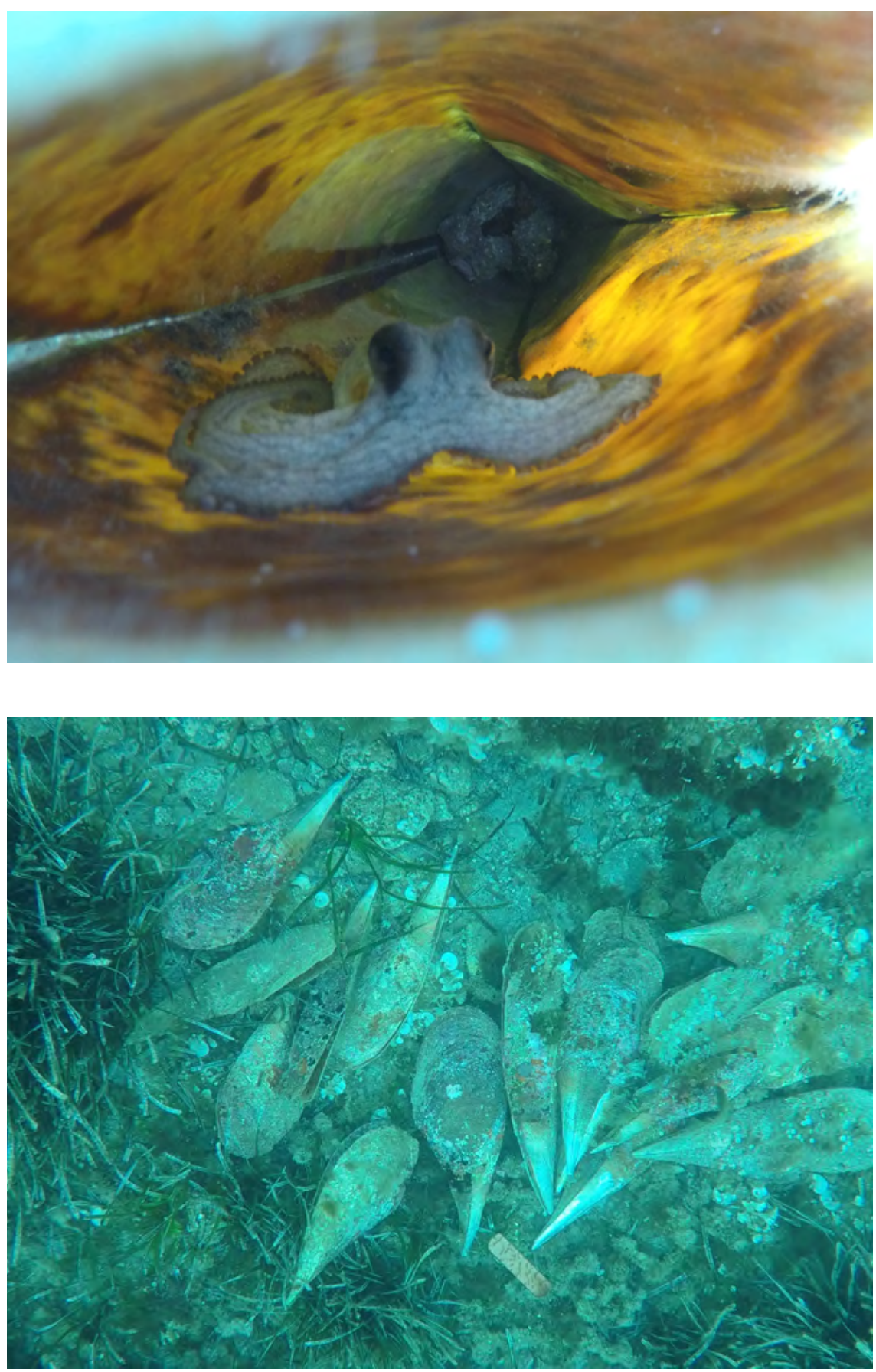

Figure 5 Empty shell of Pinna nobilis used as lair by Octopus vulgaris.

Photo by Fabio Scarpa
Figure 6 Individuals of Pinna nobilis found dead, with shells detached completely from the bottom and stacked by the current.

Photo by Fabio Scarpa by studies on mortality events in other bivalves. Indeed, protozoans in general, or haplosporidian endoparasites more specifically, have been widely recognized as the etiological agents of several diseases which caused mass mortality in many bivalve populations (see Ford and Haskin, 1982; Burreson and Ford, 2004; Laing et al., 2014), and probably for this reason first studies on the fan mussels MME causes focused their attention on protozoans (Vazquez-Luis et al., 2017; Daribba, 2017; Catanese et al., 2018; Katsanevakis et al., 2019; López-Sanmartín et al., 2019; Panarese et al., 2019; Tiscar et al., 2019). 
However, recent researches flanked several bacteria species to $H$. pinnae as potential pathogens involved in the mass mortality of P. nobilis (Carella et al. 2019, 2020; Prado et al., 2020; Lattos et al., 2020, Šarić et al., 2020; Scarpa \& Sanna et al., 2020). In particular, the new pathogens found in fan mussels affected by MME, were Mycobacterium spp. and Vibrio spp. Noteworthy, Scarpa \& Sanna et al. (2020) further retrieved in moribund or dead individuals three taxonomic entities of Mycobacterium sp. so far never described.

Remarkably, several studies report only species of bacteria found in the tissues of fan mussels that were found dead as consequence of MME but not infected by $H$. pinnae (see i.a. Pavlinec et al., 2020). Consistently, in one of the most recent epidemiological surveys on this topic (Scarpa \& Sanna et al., 2020), the lack of $H$. pinnae was evidenced in the tissues of many individuals showing the typical signs of the MME-linked disease, along with the unpredicted presence of this protozoan in living healthy individuals. Scarpa \& Sanna et al. (2020) also found $H$. pinnae in Mediterranean specimens of Ruditapes decussatus collected in 2014. This is suggestive of the fact that $H$. pinnae is not host specific for $P$. nobilis, as it was initially hypothesized (Catanese et al., 2018), and that this pathogen was already present in the Mediterranean basin years earlier the start of MME, at least since 2014 (Scarpa \& Sanna et al., 2020). Furthermore, the finding in fan mussels with the signs of the disease of the bacteria Rhodococcus erythropolis (Scarpa \& Sanna et al., 2020) and Perkinsus sp. (Carella et al., 2020) associated with Mycobacterium sp., even if in a very few individuals, suggests that further light should be shed on the identification of pathogens potentially involved in the mass mortality.
Lastly, it should be pointed that the disease related to MME of $P$. nobilis does not involve the congeneric species, the spiny fan mussel or rough pen shell Pinna rudis, which appeared unaffected by the mortality even when potential pathogens are isolated in its tissues (Vázquez-Luis et al. 2017; Scarpa \& Sanna et al. 2020). In this context, Vázquez-Luis et al. (2021) found evidences of natural hybridization between $P$. nobilis and $P$. rudis, which seems to produce individuals with a resistance capability to the illness. This recent finding, even if cannot prevent the extinction of P. nobilis, could allow at least part of its genetic heritage to survive in new populations of hybrids and introgressed individuals.

\section{DNA doesn't lie: the importance of genetic studies before and after MME}

Despite the conservational prominence of $P$. nobilis, a low number of studies were devoted to investigate the genetic structure of this species. In particular, very few molecular surveys have been conducted on samples collected before that MME led to a tremendous decay of its populations across the whole Mediterranean Sea (see Katsares et al., 2008; Rabaoui et al., 2011; Sanna et al., 2013; Wesselmann et al., 2018). The main aim of these papers was to infer on the genetic variability of populations of $P$. nobilis after the incredible demographic recovery developed as a consequence of the strict regime of protection begun in the ' $90 \mathrm{~s}$. Katsares et al. (2008) investigated the genetic variability in four Aegean populations by means of two mitochondrial markers with different putative rates of genetic variation, they were the Cytochrome c Oxidase subunit I (COI) and the 16S ribosomal subunit genes. A high level of haplotypic diversity was found for the COI gene, whereas the most conserved 16S gene showed a lower level of variability. These results suggested the lack of genetic structuring for P. nobilis within Aegean 
Sea. Rabaoui et al. (2011) used the COI gene to depict the genetic variability of five populations from the northern, eastern, and southern Tunisian coasts. A North-East decreasing gradient of genetic variability, involving areas from both western and eastern Mediterranean basins, was found among populations, which was likely involved with the variance in the hydrodynamic regime of the areas analyzed. Sanna et al. (2013) provided the first whole Mediterranean-scale insight into the genetic variability of $P$. nobilis, analyzing sites from western and eastern Mediterranean, Ionian Sea, and Adriatic Sea. To reach their goal, authors analysed samples from 25 sites - collected using for the first time a non-lethal sampling method using two mitochondrial markers (COI and 16S), in order to merge the sequences they obtained with those already provided by Katsares et al. (2008) and Rabaoui et al. (2011). Results suggested a very good health for $P$. nobilis throughout the whole Mediterranean basin, pointing out high levels of genetic variability with a good genetic connectivity among marine ecoregions (Bianchi, 2007). Wesselmann et al. in 2018 flanked nuclear microsatellites markers (developed by GonzálezWangüemert et al., 2015) to the mitochondrial COI gene to infer on the genetic connectivity among $P$. nobilis populations at large and small geographic scale. They sequenced the COI gene for six populations of the western coast of Spain, merging data with those obtained by Sanna et al. (2013). The findings further corroborate previous results, evidencing high levels of diversity within the whole Mediterranean basin with low interpopulation genetic differentiation. The analysis of microsatellite genotypes among Spanish populations showed a moderate level of genetic structuring. Although this study was published in 2018, at the time of sampling the consequences of the incoming MME on the density of individuals were probably not yet evident.
Hoping that the current trend towards extinction can be reversed, it would also be useful to provide an extended post-epidemic molecular survey, for a deeper understanding of the evolutionary forces (e.g. genetic drift, natural selection) that could underlie the mechanisms of maintenance and recovery of genetic variability following the sudden fan mussel population collapses. Furthermore, the recent molecular studies (González-Wangüemert et al., 2019; Wesselmann et al., in 2018), carried out to reconstruct the genetic connectivity patterns on the basis of hydrodynamic modelling, would also be of great help to identify effective sourcesink population pathways. Lastly, previous genetic knowledge may be useful to design proper projects for the recovery of $P$. nobilis based on the restocking of its populations strongly decayed: e.g., the assessment of the genetic structure of donor populations (if any left) would help to avoid possible phenomena of genetic pollution sensu lato (i.e., introduction in a given area of wild genetic variants with different geographic origins) in the receiving area, that might represent a deleterious occurrence for the long-term recovery potential of a species.

\section{CONCLUSION}

\section{Will there be a happy ending? Final remarks}

Currently the conservation status of the species $P$. nobilis is heavily compromised, so hard that this species has been included by IUCN among those considered as 'critically endangered' (Kersting et al., 2020). From a management point of view, a further issue is represented by the poor knowledge about the conservation status of the populations inhabiting the southern Mediterranean coasts while most of the information are obtained on the northern Mediterranean coasts. Indeed, any future 
program of protection of the species in the whole Mediterranean should include both the updated conservation status of southern populations and the connectivity between southern and northern ones.

Retracing backwards its conservation history we understood that human activity has always been its main trouble. In such a context, the very high level of protection to which $P$. nobilis was subjected at the end of the past century allowed the fully recovery of the species in less than a decade. This evidence leads to the conclusion that, if implemented promptly, protection regimes are indispensable and compulsory for a good conservation and management of an endangered species with a good own potential for recovery.

On the other hand, protection programs are not able to help species when they are facing threats such as an epidemic, in particular when the causes are not deeply known. This is the case of $P$. nobilis, whose MME is probably due to a rapidly spreading pathogens-linked disease with high rates of contagiousness and mortality. Unfortunately, at present the causes of this phenomenon are far from being completely understood and according to the current knowledge, a multifactorial disease seems to be the most probable responsible factor which is favouring the MME of P. nobilis.

Therefore, in order to adopting specific measures to stem the MME and to perform effective protection for the surviving fan mussels, it is pivotal to fill the gap on the knowledge of the disease-related pathogens composition as quick as possible. At the same time, further deep surveys focused on the socalled sentinel species (see Scarpa \& Sanna et al., 2020 for details on bivalves sentinel species) are needed in order to bypass the bias represented by the low number of available still living fan mussels to be analysed. Indeed, sentinel species, which are selected among filter feeders (e.g. Mytilus galloprovincialis and $R$. decussatus, as in Scarpa \& Sanna et al., 2020), can host the same pathogens as $P$. nobilis, thus allowing to easily evidence the occurrence of potentially dangerous etiological agents even in restocking candidate areas were $P$. nobilis disappeared.

\section{ACKNOWLEDGEMENT}

We are indebted to the Regione Autonoma della Sardegna-RAS who financed the project "Piano di Azione Regionale per la conservazione di Pinna nobilis" (Allegato alla Delib.G.R. n. 61/39 del 18.12.2018).

\section{CONFLICT OF INTEREST}

The authors declared that there is no conflict of interest.

\section{REFERENCES}

Addis P, Secci M, Brundu G, Manunza A, Corrias S, Cau A. 2009. Density, size structure, shell orientation and epibiontic colonization of the fan mussel Pinna nobilis L. 1758 (Mollusca: Bivalvia) in three contrasting habitats in an estuarine area of Sardinia (W Mediterranean). Sci Mar, 73(1), 143-52. doi.org/10.3989/scimar.2009.73n1143
Bianchi CN. 2007. Biodiversity issues for the forthcoming tropical Med Sea. Hydrobiol, 580(1), 7-21.

Basso L, Vázquez-Luis M, García-March JR, Deudero S, Alvarez E, Vicente N, et al. 2015. The Pen Shell, Pinna nobilis. Adv Mar Biol, 71, 109-60. doi.org/10.1016/ bs.amb.2015.06.002

Burreson EM, Ford SE. 2004. Areview of recent information on the Haplosporidia, with special reference to Haplosporidium 
nelsoni (MSX disease). Aquat Living Resour, 17(4), 499-517. doi.org/10.1051/alr:2004056

Butler A, Vicente N, Gaulejac B. 1993. Ecology of the pterioid bivalves Pinna bicolor Gmelin and Pinna nobilis L. Mar Life, 3 (1-2), 37-45.

Cabanellas-Reboredo M, Vázquez-Luis M, Mourre B, Álvarez E, Deudero S, Amores Á, et al. 2019. Tracking a mass mortality outbreak of pen shell Pinna nobilis populations: A collaborative effort of scientists and citizens. Sci Rep, 9(1), 1-11. doi.org/10.1038/s41598-019-49808-4

Carella F, Aceto S, Pollaro F, Miccio A, Iaria C, Carrasco N, et al. 2019. A mycobacterial disease is associated with the silent mass mortality of the pen shell Pinna nobilis along the Tyrrhenian coastline of Italy. Sci Rep, 9(1), 2725. org/10.1038/ s41598-018-37217-y

Carella F, Elisabetta A, Simone F, Fulvio S, Daniela M, Prado P, et al. 2020. In the wake of the ongoing mass mortality events: Co-occurrence of Mycobacterium, Haplosporidium and other pathogens in Pinna nobilis collected in Italy and Spain (Mediterranean Sea). Front Mar Sci, 7, 48. doi. org/10.3389/fmars.2020.00048

Catanese G, Grau A, Valencia J, García-March JR, VazquezLuis M, Alvarez E, et al. 2018. Haplosporidium pinnae sp. nov., a haplosporidan parasite associated with mass mortalities of the fan mussel, Pinna nobilis, in the Western Mediterranean Sea. J Invertebr Pathol, 157, 9-24. doi. org/10.1016/j.jip.2018.07.006

Čelebičić M, Gradaščević N, Viteškić V. 2020. Is Pinna nobilis L. critically endangered in Neum bay, Bosnia and Herzegovina? Veterinaria, 69(3), 221-7.

Coll M, Piroddi C, Steenbeek J, Kaschner K, Lasram FBR, Aguzzi J, et al. 2010. The biodiversity of the Mediterranean Sea: estimates, patterns, and threats. PloS one, 5(8), e11842 doi.org/10.1371/journal.pone.0011842

Corriero G, Pronzato R. 1987. Epibiontic sponges on the bivalve Pinna nobilis. Mar Ecol Prog Ser, 75-82.

Darriba S. 2017. First haplosporidan parasite reported infecting a member of the Superfamily Pinnoidea (Pinna nobilis) during a mortality event in Alicante (Spain, Western Mediterranean). J. Invertebr Pathol, 148, 14-9. doi. org/10.1016/j.jip.2017.05.006

De Gaulejac B, Henry M, Vicente N. 1995. An ultrastructural study of gametogenesis of the marine bivalve Pinna nobilis (Linnaeus 1758) Oogenesis. J Molluscan Stud, 61(3), 375392. doi.org/10.1093/mollus/61.3.375

De Gaulejac B, Vicente N. 1990. Ecologie de Pinna nobilis (L.), mollusque bivalve sur les côtes de Corse. Essais de transplantation et expériences en milieu contrôlé. Haliotis, 10, 83-100.
Diana A, Reguzzoni M, Congiu T, Rescigno A, Sollai F, Raspanti M. 2017. The byssus threads of Pinna nobilis: A histochemical and ultrastructural study. Eur J Histochem 61(4), 2779. doi.org/10.4081/ejh.2017.2779

Ford SE, Haskin HH. 1982. History and epizootiology of Haplosporidium nelsoni (MSX), an oyster pathogen in Delaware Bay, 1957-1980. J. Invertebr Pathol, 40(1), 118141. doi.org/10.1016/0022-2011(82)90043-X

Galinou-Mitsoudi S, Vlahavas G, Papoutsi O. 2006. Population study of the protected bivalve Pinna nobilis (Linnaeus, 1758) in Thermaikos Gulf (north Aegean Sea). J Biol Res, 5, 47-53.

García-March JR, García-Carrascosa AM, Cantero ALP, Wang YG. 2006. Population structure, mortality and growth of Pinna nobilis Linnaeus, 1758 (Mollusca, Bivalvia) at different depths in Moraira bay (Alicante, Western Mediterranean). Mar Biol, 150(5), 861-71. doi.org/10.1007/ s00227-006-0386-1

Garcia-March JR, Marquez-Aliaga A, Wang YG, Surge D, Kersting DK. 2011. Study of Pinna nobilis growth from inner record: How biased are posterior adductor muscle scars estimates? J. Exp Mar Biol Ecol, 407(2), 337-44. doi. org/10.1016/j.jembe.2011.07.016

García-March JR, Hernandis S, Vázquez-Luis M, Prado P, Deudero S, Vicente N, et al. 2020a. Age and growth of the endangered fan mussel Pinna nobilis in the western Mediterranean Sea Mar Environ Res 153, 104795. doi. org/10.1016/j.marenvres.2019.104795

García-March JR, Tena J, Henandis S, Vázquez-Luis M, López D, Téllez C, et al. 2020b. Can we save a marine species affected by a highly infective, highly lethal, waterborne disease from extinction? Biol Conserv, 243, 108498. doi. org/10.1016/j.biocon.2020.108498

Giacobbe S. 2002. Epibiontic mollusc communities on Pinna nobilis L. (Bivalvia, Mollusca). J Nat Hist, 36(12), 1385-96. doi.org/10.1080/00222930110056892

Gonzalez-Wanguemert M, Costa J, Basso L, Duarte CM, Serrão E, Hendriks I. 2015. Highly polymorphic microsatellite markers for the Mediterranean endemic fan mussel Pinna nobilis. Mediterr Mar Sci, 16(1), 31-5.doi.org/10.12681/ mms.949

González-Wangüemert M, Basso L, Balau A, Costa J, Renault L, Serrão EA, et al. 2019. Gene pool and connectivity patterns of Pinna nobilis in the Balearic Islands (Spain, Western Mediterranean Sea): Implications for its conservation through restocking. Aquat Conserv, 29(2), 175-88. doi.org/10.1002/ aqc. 2976

Gosling EM. 2003. Bivalve molluscs. Blackwell Pub. doi. org/10.1002/9780470995532 
Greenwald M. 1996. The cruising chef cookbook, Paradise Cay publication.

Hendriks IE, Tenan S, Tavecchia G, Marbà N, Jordà G, Deudero S, et al. 2013. Boat anchoring impacts coastal populations of the pen shell, the largest bivalve in the Mediterranean Biol Conserv, 160, 105-13. doi.org/10.1016/j.biocon.2013.01.012

Heywood VH. 1995. Global biodiversity assessment. Cambridge: University Press.

IOPR. 2003. Premier séminaire international sur la grande nacre de Méditerranée: Pinna nobilis. Mémoires Inst. océanographique Paul Ricard 134.

Katsanevakis S, Tsirintanis K, Tsaparis D, Doukas D, Sini M, Athanassopoulou F, et al. 2019. The cryptogenic parasite Haplosporidium pinnae invades the Aegean Sea and causes the collapse of Pinna nobilis populations. Aquat Invasions, 14(2), 150-64. doi.org/10.3391/ai.2019.14.2.01

Katsanevakis S, Poursanidis D, Issaris Y, Panou A, Petza D, et al. 2011. "Protected" marine shelled molluscs: thriving in Greek seafood restaurants. Mediterr. Mar. Sci., 11(2), 429438.

Katsares V, Tsiora A, Galinou-Mitsoudi S, Imsiridou A. 2008. Genetic structure of the endangered species Pinna nobilis (Mollusca: Bivalvia) inferred from mtDNA sequences. Biologia, 63, 412-7.

Kersting D, Benabdi M, Čižmek H, Grau A, Jimenez C, Katsanevakis S, et al. 2020. Pinna nobilis, su IUCN Red List of Threatened Species, Versione 2020.2, IUCN.

Kersting D, Benabdi M, Čižmek H, Grau A, Jimenez C, et al. 2019. Pinna nobilis. The IUCN Red List of Threatened Species 2019, e.T160075998A160081499, 24 pp.

Laing I, Dunn P, Peeler E, Feist S, Longshaw M. 2014. Epidemiology of Bonamia in the UK, 1982 to 2012. Dis Aquat Org, 110 (1-2), 101-111. doi.org/10.3354/dao02647.

Lande R. 1993. Risks of population extinction from demographic and environmental stochasticity and random catastrophes. Am Nat, 142(6), 911-27.

Lattos A, Giantsis IA, Karagiannis D, Michaelidis B. 2020. First detection of the invasive Haplosporidian and Mycobacteria parasites hosting the endangered bivalve Pinna nobilis in Thermaikos Gulf, North Greece. Mar Environ Res, 155, 104889. doi.org/10.1016/j.marenvres.2020.104889

López-Sanmartín M, Catanese G, Grau A, Valencia JM, García-March JR, Navas JI. 2019. Real-Time PCR based test for the early diagnosis of Haplosporidium pinnae affecting fan mussel Pinna nobilis. PloS one, 14(2), e0212028. doi. org/10.1371/journal.pone.0212028
Maeder F. 2008. Sea-silk in aquincum: first production proof in antiquity. Purpureae Vestes II. Textiles and Dyes in Antiquity, 109-118.

Maeno Y, Yurimoto T, Nasu H, Ito S, Aishima N, Matsuyama T, et al. 2006. Virus-like particles associated with mass mortalities of the pen shell Atrina pectinata in Japan. Dis Aquat Org, 71, 169-73. doi.org/10.3354/dao071169

Öndes F, Alan V, Akçalı B, Güçlüsoy H. 2020b. Mass mortality of the fan mussel, Pinna nobilis in Turkey (eastern Mediterranean). Mar Ecol, 41(5), e12607. doi.org/10.1111/ maec. 12607

Öndes F, Kaiser MJ, Güçlüsoy H. 2020a. Human impacts on the endangered fan mussel, Pinna nobilis. Aquat Conserv Mar Freshw Ecosyst, 30, 31-41.

Panarese R, Tedesco P, Chimienti G, Latrofa MS, Quaglio F, Passantino G, et al. 2019. Haplosporidium pinnae associated with mass mortality in endangered Pinna nobilis (Linnaeus 1758) fan mussels. J. Invertebr Pathol, 164, 32-7. doi. org/10.1016/j.jip.2019.04.005.

Pavlinec Z, Zupičić IG, Oraić D, Petani B, Mustać B, Mihaljević Z, et al. 2020. Assessment of predominant bacteria in noble pen shell (Pinna nobilis) collected in the Eastern Adriatic Sea. Environ Monit Assess, 192(9), 1-10.

Peharda M, Vilibic I. 2008. Modelling the recruitment effect in a small marine protected area: the example of saltwater lakes on the Island of Mljet (Adriatic Sea). Acta Adriat, 49(1), 25-35.

Prado P, Carrasco N, Catanese G, Grau A, Cabanes P, Carella F, et al. 2020. Presence of Vibrio mediterranei associated to major mortality in stabled individuals of Pinna nobilis L. Aquaculture, 519, 734899. doi.org/10.1016/j. aquaculture.2019.734899

Rabaoui L, Tlig-Zouari S, Ben Hassine OK. 2008. Distribution and habitat of the fan mussel Pinna nobilis Linnaeus, 1758 (Mollusc: Bivalvia) along the northern and eastern Tunisian coasts. Cah Biol Mar, 49(1), 67-78.

Rabaoui L, Tlig-Zouari S, Cosentino A, Ben Hassine OK. 2009. Associated fauna of the fan shell Pinna nobilis (Mollusca: Bivalvia) in the northern and eastern Tunisian coasts. Sci Mar, 73(1), 129-41. doi.org/10.3989/scimar.2009.73n1129

Rabaoui L, Tlig-Zouari S, Katsanevakis S, Hassine OKB. 2010. Modelling population density of Pinna nobilis (Bivalvia) on the eastern and southeastern coast of Tunisia. J. Molluscan Stud, 76(4), 340-7. doi.org/10.1093/mollus/eyq023

Rabaoui L, Mejri R, Tlig-Zouari S, Bahri L, Hassine OKB. 2011. Genetic variation among populations of the endangered fan mussel Pinna nobilis (Mollusca: Bivalvia) along the Tunisian coastline. Hydrobiologia 678, 99-111. doi. org/10.1007/s10750-011-0827-9 
Rabaoui L, Belgacem W, Ben Ismail D, Mansour L, TligZouari S. 2015. Engineering effect of Pinna nobilis shells on benthic communities. Oceanologia 57 (3), 271-279.

Rouanet E, Trigos S, Vicente N. 2015. From youth to death of old age: The 50-year story of a Pinna nobilis fan mussel population at Port-Cros Island (Port-Cros National Park, Provence, Mediterranean Sea). Sci Rep Port-Cros Natl Park, 29, 209-22.

Richardson CA, Peharda M, Kennedy H, Kennedy P, Onofri, V. 2004. Age, growth rate and season of recruitment of Pinna nobilis (L) in the Croatian Adriatic determined from $\mathrm{Mg}$ : Ca and Sr: Ca shell profiles. J Exp Mar Biol Ecol, 299(1), 1-16. doi.org/10.1016/j.jembe.2003.08.012

Sanna D, Cossu P, Dedola GL, Scarpa F, Maltagliati F, Castelli A, et al. 2013. Mitochondrial DNA Reveals Genetic Structuring of Pinna nobilis across the Mediterranean Sea. PLoS ONE, 8(6), e67372. doi.org/10.1371/journal pone. 0067372

Sanna D, Dedola G, Scarpa F, Lai T, Cossu P, Curini-Galletti M, et al. 2014. New mitochondrial and nuclear primers for the Mediterranean marine bivalve Pinna nobilis. Mediterr. Mar Sci, 15(2), 416. doi.org/10.12681/mms.459

Šarić T, Župan I, Aceto S, Villari G, Palić D, De Vico G, et al. 2020. Epidemiology of Noble Pen Shell (Pinna nobilis L. 1758) Mass Mortality Events in Adriatic Sea Is Characterised with Rapid Spreading and Acute Disease Progression. Pathogens, 9, 776. doi.org/10.3390/pathogens9100776

Scarpa F, Marcia P, Cossu P, Lai T, Sechi S, Curini-Galletti $\mathrm{M}$, et al. 2019. Marine strategy as needful tool for the management of endangered species: The study case of Pinna nobilis (Mollusca: Bivalvia). Biol Mar Mediterr, 26, 121-2.

Scarpa F, Sanna D, Azzena I, Mugetti D, Cerruti F, Hosseini S, et al. 2020. Multiple non-species-specific pathogens possibly triggered the mass mortality in Pinna nobilis. Life, 10(10), 238. doi.org/10.3390/life10100238

Schultz PW, Huber M. 2013. Revision of the worldwide Recent Pinnidae and some remarks on fossil European Pinnidae. Acta Conc, 13, 1-164.
Tiscar PG, Rubino F, Fanelli G, Paoletti B, Della Salda L. 2019. Mass mortality of the fan mussel Pinna nobilis in Apulia (Ionian Sea) caused by Haplosporidium pinnae. Rapport Commission International pour l'exploration scientifique de la Mer Mediterranée, 42, 30.

Trigos S, Vicente N, Prado P, Espinós FJ. 2018. Adult spawning and early larval development of the endangered bivalve Pinna nobilis. Aquaculture, 483, 102-10. doi. org/10.1016/j.aquaculture.2017.10.015

Vázquez-Luis M, Borg JA, Morell C, Banach-Esteve G, Deudero S. 2015. Influence of boat anchoring on Pinna nobilis: A field experiment using mimic units. Mar Freshw Res, 66(9), 786-94. doi.org/10.1071/MF14285

Vázquez-Luis M, Álvarez E, Barrajón A, García-March JR, Grau A, Hendriks IE, et al. 2017. S.O.S. Pinna nobilis: A Mass Mortality Event in Western Mediterranean Sea Front Mar Sci, 4, 220. doi.org/10.3389/fmars.2017.00220

Vázquez-Luis M, Nebot-Colomer E, Deudero S, Planes S, Boissin, E. 2021. Natural hybridization between pen shell species: Pinna rudis and the critically endangered Pinna nobilis may explain parasite resistance in $P$. nobilis. Mol Biol Rep, 1-8. doi.org/10.1007/s11033-020-06063-5

Voultsiadou E, Koutsoubas D, Achparaki M. 2010. Bivalve mollusc exploitation in Mediterranean coastal communities: an historical approach. J Biol Res, 13, 35.

Walpole MJ, Leader-Williams N. 2002. Tourism and flagship species in conservation. Biodivers Conserv, 11, 543-7. doi. org/10.1023/A:1014864708777

Wesselmann M, González-Wangüemert M, Serrão EA, Engelen AH, Renault L, García-March JR, et al. 2018. Genetic and oceanographic tools reveal high population connectivity and diversity in the endangered pen shell Pinna nobilis. Sci Rep, 8(1), 1-11. doi.org/10.1038/s41598-018-23004-2

Zavodnik D, Hrs-Brenko M, Legac M. 1991. Synopsis on the fan shell Pinna nobilis L. in the eastern Adriatic Sea. In: Les Espèces Marines à Protéger en Méditerranée, (eds., C.F. Boudouresque, M. Avon, V. Gravez), Gis Posidonie Publ. Marseille, pp. 169-78. 


\section{OD TAME DO SVJETLOSTI I NAZAD: DA LI JE PINNA NOBILIS, NAJVEĆA MEDITERANSKA ŠKOLJKA NA RUBU IZUMIRANJA?}

\section{SAŽETAK}

Pinna nobilis je najveći školjkaš Mediteranskog mora i predstavlja posebnu vrstu koja privlači ljudsku pažnju. Kao moguća posljedica određenih ljudskih djelatnosti početkom 80 -ih, populacija lepezastih školjki je doživjela ozbiljan demografski pad. Da bi se ovaj trend preokrenuo, P. nobilis je uključena u režim potpune zaštite koji je početkom milenija doveo do znatnog oporavka vrste. Nažalost, $P$. nobilis se trenutno suočava sa dramatičnom epidemijom koja je ovu školjku dovela na rub izumiranja. Taj fenomen je prvi put zabilježen u ranu jesen 2016. godine na mediteranskim obalama Španije. Od tada se masovno ugibanje brzo širi prema istoku zahvatajući skoro sva područja Mediterana. Prva epidemiološka istraživanja su masovna ugibanja $P$. nobilis pripisala protozoi Haplosporidium pinnae, ali su nedavna istraživanja ukazala na ulogu nekih bakterija iz rodova Mycobacterium i Vibrio kao alternativnih uzročnika. Trenutno se najvjerovatnijim faktorom odgovornim za ovaj fenomen smatra udruženo djelovanje nekoliko patogena koji djeluju multifaktorijalno izazivajući bolest. Uprkos konzervatorskom djelovanju na $P$. nobilis, mali broj studija je ispitivao genetsku strukturu ove vrste prije masovnog ugibanja i sve su dovele do zaključka da su populacije u cijelom Mediteranu veoma dobrog zdravstvenog stanja sa velikom genetskom varijabilnošću i dobrom genetskom povezanošću između područja. Trenutno bi bilo veoma korisno provesti opsežno postepidemijsko molekularno istraživanje, a u svrhu boljeg razumijevanja uzroka masovnog ugibanja lepezastih školjki.

Ključne riječi: Lepezasta školjka, ugrožena vrsta, masovno ugibanje, etiološki uzročnici, genetske analize 